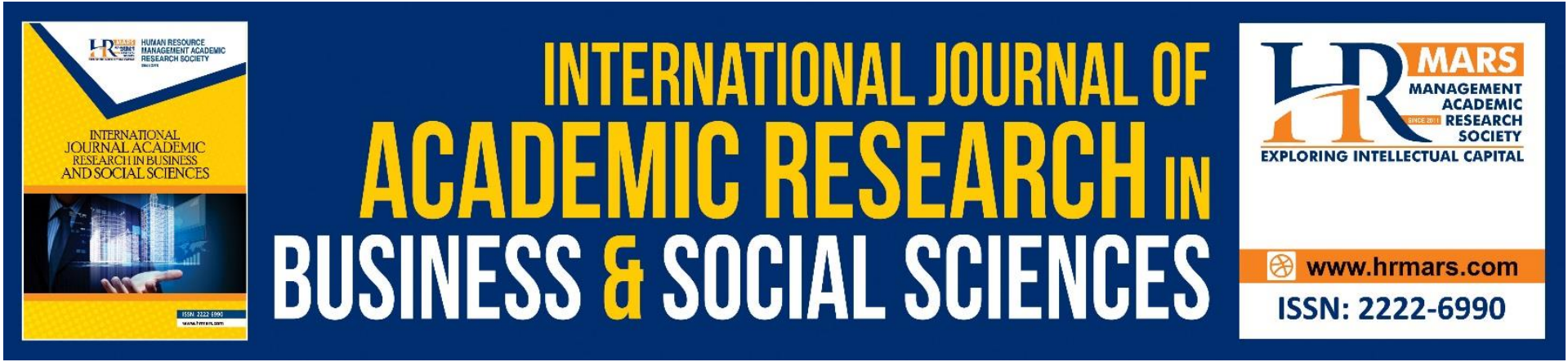

\title{
Gender Analyses on the Vulnerability Types Suffered by Poor and Older Freshwater Fisheries Community Members in Peninsular Malaysia
}

Norehan Saidi, Zumilah Zainalaludin \& Askiah Jamaluddin

To Link this Article: http://dx.doi.org/10.6007/IJARBSS/v11-i12/11935

DOI:10.6007/IJARBSS/v11-i12/11935

Received: 09 October 2021, Revised: 11 November 2021, Accepted: 27 November 2021

Published Online: 20 December 2021

In-Text Citation: (Saidi et al., 2021)

To Cite this Article: Saidi, N., Zainalaludin, Z., \& Jamaluddin, A. (2021). Gender Analyses on the Vulnerability Types Suffered by Poor and Older Freshwater Fisheries Community Members in Peninsular Malaysia. International Journal of Academic Research in Business and Social Sciences, 11(12), 2046-2069.

Copyright: (c) 2021 The Author(s)

Published by Human Resource Management Academic Research Society (www.hrmars.com) This article is published under the Creative Commons Attribution (CC BY 4.0) license. Anyone may reproduce, distribute, translate and create derivative works of this article (for both commercial and non0-commercial purposes), subject to full attribution to the original publication and authors. The full terms of this license may be seen at: http://creativecommons.org/licences/by/4.0/legalcode

Vol. 11, No. 12, 2021, Pg. 2046- 2069

Full Terms \& Conditions of access and use can be found at http://hrmars.com/index.php/pages/detail/publication-ethics 


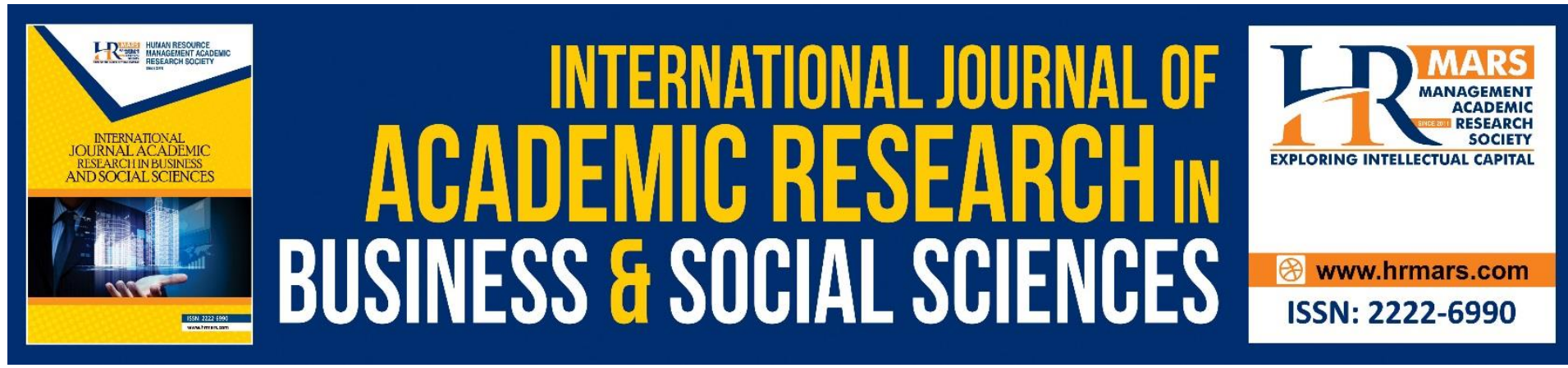

\title{
Gender Analyses on the Vulnerability Types Suffered by Poor and Older Freshwater Fisheries Community Members in Peninsular Malaysia
}

\author{
${ }^{1}$ Norehan Saidi, 1,2Zumilah Zainalaludin \& ${ }^{1}$ Askiah Jamaluddin \\ ${ }^{1}$ Faculty of Human Ecology, Universiti Putra Malaysia, 43400 Serdang, Selangor Darul Ehsan, \\ ${ }^{2}$ Malaysian Research Institute on Ageing, Universiti Putra Malaysia, 43400 Serdang, Selangor \\ Darul Ehsan. \\ Email: zumilah@upm.edu.my
}

\begin{abstract}
This paper aimed to measure the vulnerability type that predicts the likelihood of the respondents in poor category of household income by sex-disaggregated data. The respondents were sampled in Peninsular Malaysia $(n=322))$. They suffer from at least one out of six types of vulnerability asked in the questionnaire. HO1 (no type of vulnerability predicts male in poor category of household income), and $\mathrm{HO} 2$ (no type of vulnerability predicts male in poor category of household income) were tested through Binary Logistic Regression (BLR) Model respectively and rejected. Both models were fit and significant $(p<0.05)$ to predict the male and female respondents in poor category of household income. BLR Model 1 (male respondents) significantly predicted Handicapped Male and Single Father, with 3.60 times and less than 93.9 percent of the likelihood respectively for them to be in poor category of household income. For BLR Model 2 (female respondents), Single Mother and Handicapped Women predicted 16.15 times and 72.5 percent less of the likelihood respectively for them in the poor category of household income. This paper concludes the vulnerable women are poorer than the vulnerable men, and the handicapped men and single mothers are the poorest in freshwater fisheries communities.
\end{abstract}

Keywords: Poverty, Gender, Vulnerability, Handicapped, Single Mother

\section{Introduction}

The fisheries and aquaculture economic sector (FAES) consists of wild fishing as well as aquaculture farming (Tidwell \& Allan, 2015); and FAES can be categorised under three water systems - brackishwater, freshwater and marine water system. There are 15,719 aquaculture farmers in Malaysia (Department of Fisheries, Malaysia [DOF], 2020). The FAES as well as aquaculture sub sector involve masculine activities in FAES (Sataporvanit, 2018), high work risk and dangerous jobs (Stergiou-Kita et al., 2015), and are only suitable for men. There have been fishermen who are dead or disabled because of various accidents during fishing. As a result, they left behind many vulnerable single mothers (Zainalaludin, et al., 2017; Oginni et 
al., 2013) who are usually not only poor but also the caretakers of other vulnerable family members such as the elderly and bedridden family members.

Various productions of this sector from fresh fishes and shell food to various fish-based processed food products have contributed significantly to national food security (Food and Agriculture Organization [FAO], 2018); particularly freshwater aquaculture in FAES sub sector, as it produces cheap protein fish as compared to brackishwater and marine water FAES sub sectors (McIntyre et al., 2016). Thus, the importance of this sector has been recognized by various developing countries (Bahaman et al., 2009). Moreover, the national food security, FAES aquaculture sub sector also contributes in eradicating poverty among fisheries community members (United Nation, 2015), and also as a source of national income (Azer et al., 2016; Hussin \& Yik, 2012).

Poverty incident is a key factor in measuring the vulnerability (Gallardo, 2018; Fujii, 2016). To achieve SDG 1 (no poverty), the vulnerable groups need to be a key focal point in any economic sector, especially in masculine economic sector such as the FAES (Cliffe \& Akinrotimi, 2013). They are poor because they are mainly involved in low pay and unpaid works (Lentisco \& Lee, 2015), such as working as general workers with day-pay in fish-based processing food enterprises or working in seafood restaurants. Besides the low pay due to their vulnerability, they usually have low academic backgrounds as well as low job skill. While, they are part of the community members, and used to serve directly in FAES and support the fishermen or farmers who contribute to the national food security.

In order to impose some policies and programs related to poverty eradication in the community of masculine economic sector, the baseline data with regard to the type of vulnerability, gender, poverty and the relationship between those variables need to be explored so that the program can be designed to address the needs of these vulnerable groups. This paper aimed to answer the following research questions:

RQ1: what are the backgrounds of the respondents by sex disaggregation?

RQ2: what are the distributions of the respondents by the type of vulnerability and sex disaggregation?

RQ3: what is the vulnerability type that predicts vulnerable respondents in the poor category of household income by sex disaggregation?

The detailed objectives are as follows: -

RO1: to profile the backgrounds of the respondents by sex disaggregation.

RO2: to identify the distributions of the respondents by the types of vulnerability and sex disaggregation.

RO3: to measure the vulnerability type that predicts the likelihood of the respondents in the poor category of household income by sex disaggregation.

\section{Literature Review}

Poverty

Rural areas with less health infrastructure and medical services (Schneider et al., 2009) may discredit the wellbeing of poor, rural and older people (WHO, 2008). Thus, they need special programs that focus on their need and assist them with their real problems. In addition to being the family caretaker, single mother also has to work for a living (Schulz et al., 2016). 
Poverty eradication programs may be failed without knowing the focus to the actual problem of poor rural women.

Williams (2008) showed that poverty among fishermen households in Malaysia may be lower if more attention had been paid to gender dimension. in line with Ahmad, Salim, Chee, Isa and Lim (2003), the poverty rate among Malaysian fishing households was 10.2 percent and over 80 percent of fishermen had no paid employment (Yeo, 2007) and on average, 70 percent of fishing community's household income came from fishing (Solaymani \& Kari, 2014). Therefore, the community may slip into poverty. Moreover, women in fisheries community received income far below the poverty level (Giron-Nava et al., 2021; Yahaya, 2001). Solaymani and Kari (2014) also noted that fishermen in Malaysian fisheries communities, as in other developing countries, often just barely miss the poverty line.

Poverty causes hunger (SDG-2) and food security in any community, especially fisheries community (Ngaraya et al., 2019). This may be related to marginalisation and gender stereotypes (Verschelden, 2017). As a result, women and single mothers are more likely to be poor because their poverty rate is higher and their income is lower (Gamblin, 2017). According to Nazri et al. (2019), if a single mother is the poorest of the poor in her society, special attention should be paid to her situation. This is because the poverty level varies depending on the definition of a single mother as the head of household (Paweenawat \& McNown, 2014). Many countries prefer young, unmarried, and reasonably educated women in FAES or agri-food industries (Leavy \& Hossain, 2014; Islam, 2008). As a result, single mothers have fewer opportunities to earn income in the economic sector.

Furthermore, if this scenario continues in economic sector, women in the community will slip into poverty, with the situation worsening for single mothers (Zarina \& Anton, 2012; McKenzie \& Cook, 2008). This is because according to numerous studies, fishermen tend to be the poorest members of the society as they are the first to suffer from fisheries modernization and economic pressures and are marginalized even before women (Casmiwati et al., 2019; Yusri \& Ramli, 2016). Therefore, to tackle the problem of household poverty and improve their quality of life, they ensure that their family is productive in the economic sector, especially their wife and child (Yusri \& Ramli, 2016). Nevertheless, the wife usually receives a small or no payment because their roles are only to help their husband (Lentisco \& Lee, 2015; International Labour Office, 2013).

\section{Conceptualization of Vulnerability and Poverty in Fisheries Community}

This paper uses the concept of vulnerability as someone with missing ability to work (Zainalaludin et al., 2017), or someone with risk to generate income for living (Qaisrani et al., 2018; Zainalaludin, 2010; Eriksen \& O'Brien, 2007; Hilhorst \& Bankoff, 2004), and without social security. Someone with a high social security is not categorised as a vulnerable individual (Kaufmann, 2008; Bolderson, 2007). Individuals with a similar vulnerability type can be in similar vulnerable groups such as the group of single mothers and older people. Besides being vulnerable and poor, this paper also refers to vulnerability as the marginalisation in the community (Wrigley \& Dawson, 2016; Allison et al., 2006; Ringbäck-Weitoft, 2001).

This paper presents seven types of vulnerability deduced from Six Dimensions of Wellness Model (1979). On the other hand, of the wellness domains which are physical, emotional, social, intellectual/spiritual, occupational and mental disabilities (Rose \& Dark, 1985; Wolff, 
1987), are the domains of vulnerability. Nevertheless, this paper excluded mental retarded individual because he/she totally cannot work. The vulnerability types deduced from Six Dimensions of Wellness are the Handicapped, Single Parent, Older Person, Caretaker, Living Alone, Serious Diseases, and Child Labour Vulnerability Type (Table 01).

Table 01: Vulnerability Type Deduced from Six Dimensions of Wellness Model

\begin{tabular}{l|l}
\hline Dimensions of Wellness Domain & Vulnerability Type \\
\hline Physical & Handicapped \\
& Older Person \\
& Child Labour \\
\hline Emotional & Single Parent \\
& Serious Disease \\
& Caretaker \\
& Living Alone \\
\hline
\end{tabular}

Only two domains in Six Dimensions of Wellness were used in this paper to deduce seven types of vulnerability, which were the physical and emotional domains. Associated with emotional domain are Single Parents, Suffering Serious Disease, Caretaker and Living Alone Types of Vulnerability (Table 01). These seven vulnerability types are associated with marginalisation and poverty (Allison et al., 2006). For example, the respondents who are suffering from serious diseases may be due to poor exercise, poor diet and poor lifestyle, which may be caused by poverty. Serious diseases suffered by someone may also be due to the poverty stress, especially among poor women because a woman is already vulnerable in any masculine economic sector (Sadan, 2004), due to the disability of women to work like men in this sector. There is no difference between the vulnerability type in masculine economic sector than other sector communities, except that the vulnerable groups suffer more economical burden in masculine economic sector compared to in other sectors.

There may be a relationship between gender, poverty, marginalisation and vulnerability. Nevertheless, this paper only presents the gender, poverty and vulnerability without marginalisation indicator. Many studies have shown that women who are vulnerable are often vulnerable to poverty. For example, single mothers and the elderly in rural areas are frequently associated with poverty (Bradshaw et al., 2019; Masud \& Zainalaludin, 2018a; Rasool et al., 2011). They became impoverished because women live longer than men (United Nations, 2019), and are often without social security (Mohd et al., 2017) because they were previously financially dependent on their husband (Bradshaw et al., 2019; Masud \& Zainalaludin, 2018a). Many research had shown that individuals in feminism poverty are also in the category of Single Parent, Handicapped, Older Person, and Serious Disease Vulnerability Types of Vulnerability (Herten-Crabb \& Davies, 2020; Bradshaw et al., 2019; Humphrey, 2016; Morris, 2007; Anderson, 2000). Nevertheless, less research had been conducted on feminism poverty with regard to Living Alone, Caretakers, and Child Labour Types of Vulnerability (Herten-Crabb et al., 2019; Humphrey, 2016; Morris, 2007; Anderson, 2000). Feminism poverty is described as the measurement of women's poverty based on household income and consumption. The latter is determined by socio-economic factors, such as age, academic background, location, employment, house or land ownership and marital status (Moghadam, 2005), because of the rise in feminism poverty rates, especially among rural women and women in developing countries (Bradshaw et al., 2019; Chulu, 2015; Veeran, 2000; Minkler \& Stone, 1985). 
Women gender roles are closely associated with household chores. Thus, they are more dynamic than men in the private sphere (Reinharz, 1984) who are close to their children and neighbours (Feldman \& Stall, 1992). However, to generate income, women always encounter many obstacles because in the public sphere, men are significant, especially in freshwater aquaculture FAES. Moreover, men have no or less gender roles in the private sphere. Due to women gender roles, poor rural women usually work from home or close to their homes. In addition to gender roles, women are also the caretaker of their children and older family members. The gender roles cause women to suffer various family-work challenges in their life (Shah \& Shah, 2016). Thus, this paper analysed the data by sex disaggregation in order to identify the severity of vulnerability among women as compared to men.

In every community, there are more single mothers with children than single fathers with children (United Nation, 2015). Single mothers tend to be poorer than single fathers (Dommaraju et al., 2011). Poor single mothers and older women with low academic background, no work experience and unable to do heavy work cannot earn much from their work in male aquaculture FAES (Techane, 2018; Yang, 2018). From the gender perspective, a successful man is a rich man and fulfils his valuable social roles, while a successful woman is married, a mother, mature, responsible and caring (Luttrell, 1988). Therefore, poor single mothers may suffer more from gender stereotypes than single fathers in the community (Lee, 2020).

Generally, FAES involves masculine activities in which women cannot perform the work as men do (Chintey \& Chintey, 2014). Older Person Type of Vulnerability who suffers from physical deterioration and, moreover, the poor and older single mothers who live alone, are facing quadruple burden - poor economic security, poor political influence, poor social support (Cox, 1988) and are prone to Serious Diseases Vulnerability Type (Backers et al., 2008). The Living Alone Type of Vulnerability refers to emotional domain of Six Dimensions of Wellness Model which refers to someone who lives alone without a spouse, adult children, other relatives or friends (Thapa et al., 2018). This type of vulnerability may increase the risk of loneliness and stress (Lim \& Kua, 2011) because as social creatures, people need friends and company. In the long term, stress may cause poor health and leads to death (Salleh, 2008).

This paper reported on the elderly, the handicapped, single parent, living alone and the individual suffering from serious disease(s) as the vulnerable groups. In fisheries community, the masculine activities in FAES need an able body and strong men to do the work (Siswanto et al., 2021). For example, in aquaculture farming, activities such as carrying the fish basket, cleaning the ponds, and repairing aquaculture fishing gears (Siswanto et al., 2021; Sornkling et al., 2018) are heavy jobs which need masculine energy of men. Thus, handicapped men, women and the elderly cannot do these kind of works. These jobs are risky too which will be dangerous to women and the elderly. Basically, there is no difference between the types of vulnerable groups by economic sector. Nevertheless, the masculine economic sector such as the fisheries, aquaculture and agriculture may harm the vulnerable groups more than other economic sectors economically.

Poverty incidents are rampant in fishermen community (Frongillo et al., 2019), which may be due to the rurality of fishermen geographical areas (Zain, et al., 2021; Bertolini, 2019; Nair 
\& Sagaran, 2017), low academic backgrounds of the community members (Zainalaludin, 2012), and less economic activities except fishing, small eco-tourism and small processed food activities. Poverty may then lead to poor life wellbeing (Hartline-Grafton \& Dean, 2017; Rojas, 2015) due to the lack of medical and educational facilities, healthcare infrastructures (Kumar, 2018; Solaymani \& Kari, 2014; Seligman et al., 2010). This situation is even worse for vulnerable groups because they are not able to get involved in FAES directly as the activities in FAES are too masculine (Allison et al., 2006).

Thus, the vulnerable groups may have limited choices to earn income, and may be the poorest among the poor in any communities. To name a few, vulnerable community members comprise the handicapped individuals, poor single mothers with many dependents, the elderly, caretakers and individuals with various serious diseases. Besides vulnerability, they are prone to poverty and marginalization (Allison et al., 2006). Despite being involved directly in FAES, there is not much that they can do to earn income due to the vulnerability. All members of fisheries community have actually put a lot of effort in providing the fish food for national food security (Teh \& Pauly, 2018; HLPE, 2014). They are entitled to live in good wellbeing regardless of their disabilities. Thus, suitable programs should address the poorest vulnerable group. There is the need to firstly identify them.

In discussing the vulnerability, rural women are always associated with vulnerability (Chintey \& Chintey, 2014), because they are also usually associated with poverty and marginalisation (Allison et al., 2006), especially in rural areas and in community involved in masculine economic sectors. Rural women are usually housewives with traditional gender role in private sphere (Chant, 2006). If they work, they are usually involved in low pay jobs (Jajri, 2012; Klasen et al., 2011; Welnnerholm, 2002; Buvinic, 1997), due to the low academic background (Zumilah, 2012), and their traditional gender role responsibilities (Bradshaw et al., 2019). The high incidence of poverty among women as compared to men is one of the indicators of feminism poverty (Welnnerholm, 2002). In addition to women suffering in poverty more severe than men do; women fall into the incidence of poverty more than men; they are treated unequally, and differently than men globally (Welnnerholm, 2002).

Poor women as the head of household is a growing trend (Yoosefi et al., 2020; Nazri et al, 2019; Young, 1993; Tinker, 1990). In fisheries community, female head of household always suffers from poverty because, previously, they were dependent on their husband for a living (Bradshaw et al., 2019). Thus, when the husbands are no longer with them due to the separation, divorce or death, they may lose the household income as they cannot rely on the husband for the living.

Nevertheless, some studies claim the feminization of poverty due to the rise in poverty among adults and elderly women (Owusu-Afriyie et al., 2014; Medeiros \& Costa, 2006; Veeran, 2000), because women live longer than men (United Nations, 2019). In Malaysia, rural elderly people are usually associated with poverty (Masud \& Zainalaludin, 2018). Among the reasons are the retirement age (Mohd et al., 2017), rural women are usually housewives (Wahab et al., 2018; Islam, 2008), and women tend to get lower pay than men especially in masculine economic sector (Jajri, 2012; Klasen et al., 2011; Welnnerholm, 2002; Buvinic, 1997) during their productive age. 
Sustainable Livelihood Approach uses absolute poverty (Poverty Line Income (PLI)) which is a condition characterised by severe deprivation of basic human needs (United Nation World Summit for Economic Development, 1995), or the minimum income required by a household to meet the basic needs (Economic Planning Unit (EPU), 2014). PLI can be used to determine the number of poor households in any community. This paper used PLI $2019=$ RM2208 (DoSM, 2020) in order to identify poor households (of income equals or less than RM2208) in the data.

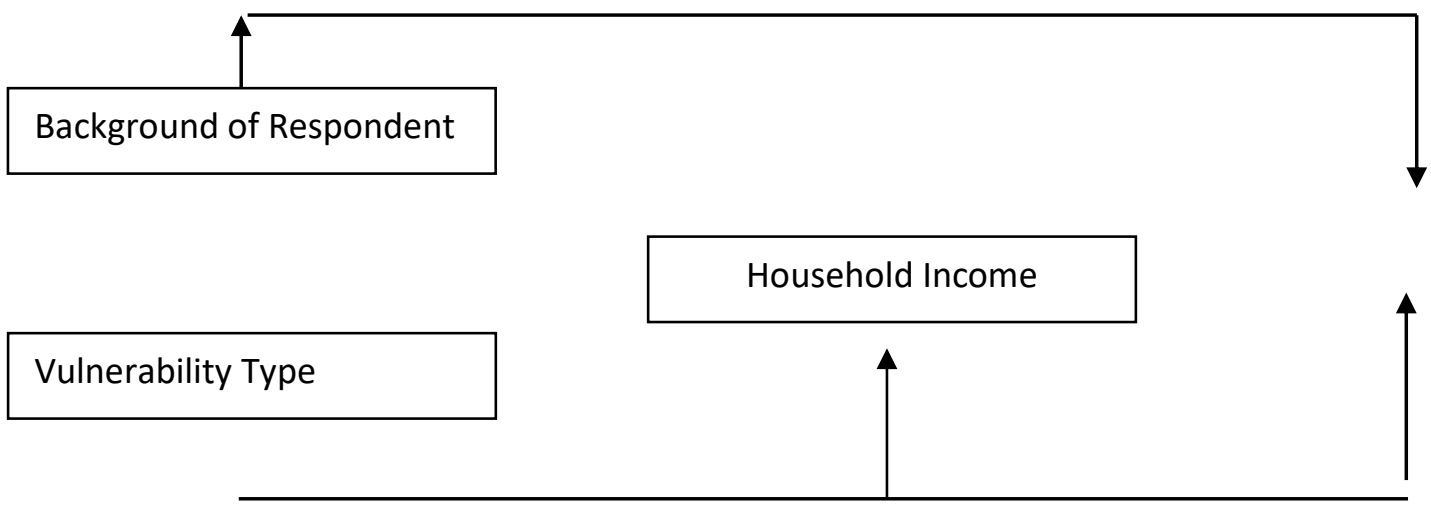

Figure 01: Conceptual Framework

\section{Theory}

\section{Social Role Theory}

Social Role Theory (Eagly, 1987) explains that men and women are segregated by gender, with individual gender behaviours differing based on gender roles (social roles) defined by community members (Eagly et al., 2000). For instance, men are expected to fulfil the argentic qualities or masculine gender roles, while women are expected to fulfil the feminine qualities of gender roles (Wood \& Eagly, 2002). Thus, the masculine economic sector of the economy is only suitable for men and carry a high work risk which may cause fatal and serious work accidents which may leave behind single mothers as well as the handicapped or disabled men in the community. Women and vulnerable groups may earn low income in masculine economic sector and it is difficult for them to escape from abject poverty.

\section{Methodology}

\section{Study Location}

This study location is at freshwater fisheries communities in four districts sampled from four zones of Peninsular Malaysia - Pekan District in Pahang State (Eastern Zone), Kuala Pilah District in Negeri Sembilan State (Southern Zone), Lenggong District in Perak State (Middle Zone), and Padang Terap District in Kedah State (Northern Zone). The districts were chosen based on the existence of freshwater fisheries communities and are considered as important places for FAES in the district, as proposed by the Department of Fisheries (DOF) office in each state.

\section{Study Design, Sample and Data Collection Process}

This study used an exploratory research and only based on a cross-sectional survey collected among the poor and vulnerable freshwater fisheries community members in Peninsular Malaysia from March to April 2019. The total population in the four sampled districts was equal to 15,719 aquaculture operators (DOF, 2020). On the average of four to six people per 
household (Zainudin et al., 2019; Asok, 2016), there were 94,314 members in the community. As according to Osman et al., (2015), 10 percent were assumed as the vulnerable people population $(N=9,431)$ for this study. According to Krejcie and Morgan Table (1970) for $N=9,431$, the sample size is $n=370$ the number of respondents. Thus, $n=400$ was used in this paper as the total number of the sample and was divided equally with 100 respondents in each district, which consisted of 50 male respondents and 50 female respondents (Table 02 ).

Table 02: Sampling Table

\begin{tabular}{|c|c|c|c|c|}
\hline Zone & District & Male & Female & Total \\
\hline Eastern & Pekan & 50 & 50 & 100 \\
\hline Southern & Kuala Pilah & 50 & 50 & 100 \\
\hline Middle & Lenggong & 50 & 50 & 100 \\
\hline Northern & Padang Terap & 50 & 50 & 100 \\
\hline \multicolumn{4}{|c|}{ Total } & 400 \\
\hline
\end{tabular}

The community leader in each district helped in identifying 400 vulnerable respondents in their respective districts (Table 02) through probability sampling. Of this number $n=322$ poor and vulnerable respondents were drawn and used in the analysis of this study. The leaders of sampled villages (JKKK) were trained as the enumerators to brief about the objectives of the survey and interview the respondents. The respondents were approached to gather the information on their background, the vulnerability types suffered by them, and their household income by using the questionnaire form. The types of vulnerability refer to the Handicapped, Single Parent, Older Person, Suffering Serious Disease, Living Alone, Caretaker and Child Labour Types of Vulnerability deduced from the Six Dimensions of Wellness Model (Table 01). The study was approved by Ethic Committee for Research Involving Human Subject Universiti Putra Malaysia (JKEUPM-2018-409).

\section{Null Hypotheses}

Two null hypotheses tested in this study are as follows:

HO1: there is no type of vulnerability that predicts the likelihood of male respondents in poor category of household income

$\mathrm{HO} 2$ : there is no type of vulnerability that predicts the likelihood of female respondents in poor category of household income

\section{Exploratory Variable}

\section{Dependent Variable - Malaysia Poverty Line Income}

The Malaysia PLI, revised in year 2019 (Department of Statistic Malaysia, 2020) which is RM2208 (USD532.24) was used to identify the poor category of household income in the data. The households with income <RM2208 (USD532.24) were categorized as poor household income in freshwater fisheries community and were drawn and used in the analysis of this study. This paper used dichotomous dependent variable (DV) which was the male/female respondent in poor category of household income $=1$, and male/female respondent in poor category of household income $=0$.

\section{Independent Variable}

Past studies showed that the vulnerability type has an impact on poor and vulnerable males and females (Bradshaw et al., 2019; Zumilah et al., 2017; Humphrey, 2016). There were seven vulnerability types listed in the questionnaire- Handicapped, Single Parent, Older Person, 
Serious Disease, Living Alone, Child Labour, and the Caretaker (Table 01) to predict the poor male and female respondents. Each independent variable (IV) was dichotomous variable which was suffer from vulnerability type $=\mathrm{YES}=1$ and not suffer from vulnerability type $=$ NO $=0$. This paper only reported three types of vulnerability- the Handicapped, Single Parent and Living Alone; because only these three have significant relationships with DV and no relationship among them.

\section{Statistical Analysis}

Descriptive statistics through frequency, percentage, mean, and standard deviation were used to profile the backgrounds of the respondents by sex disaggregation (RO-1), and the distributions of the respondents by the types of vulnerability and sex disaggregation (RO-2). For RO-3, two Binary Logistic Regression (BLR) Models were used to test null hypotheses. In addition, multicollinearity test was used for independent variable mentioned above to eliminate the variables that have strong correlation with each other. Two Binary Logistic Regression (BLR) Models are as follows: -

Model $1-$ Ln Y Poor Male $=a+b 1_{\text {handicapped }}+b 2_{\text {single parent }}+b 3_{\text {living alone }}$

\section{Notes}

i) For poor male respondents

ii) Dependent variable (DV) as follows: -

Male respondents in poor category of household income $(<R M 2208-$ USD532.34 $)=1$

Female respondents in poor category of household income $(<R M 2208-$ USD532.34 $)=0$

iii) Model significant $(p<0.05)$

iv) Handicapped, single parents and living alone significant $(p<0.05)$ relationship with DV and no multicollinearity

Model $2-\operatorname{Ln} Y_{\text {Poor Female }}=a+b 1_{\text {handicapped }}+b 2_{\text {single parent }}+b 3_{\text {living alone }}$

\section{Notes}

i) For poor female respondents

ii) Dependent variable (DV) as follows: -

Female respondents in poor category of household income $(<R M 2208-$ USD532.34 $)=1$

Male respondents in poor category of household income $(<R M 2208-U S D 532.34)=0$

iii) Model significant $(p<0.05)$

iv) Handicapped, single parents and living alone significant $(p<0.05)$ relationship with the DV and no multicollinerarity

\section{Findings and Discussion}

\section{Socio Demographic Background of the Respondent}

Table 03 below presents the descriptive data of background variable 322 of poor vulnerable respondents by sex disaggregation. The respondents in this paper are mainly from the Northern and Southern Zone of Peninsular Malaysia. Initially, there was an equal number of vulnerable respondents sampled in each zone and sex, nevertheless, good return rates received only from the Northern (26.7\%) and Southern Zones (26.7\%) of Peninsular Malaysia, and with a slightly higher number of female (54.04\%) than male $(45.96 \%)$ vulnerable respondents reported in this paper (Table 03). One of the reasons may be because of females 
are older, and females live longer than males on an average of five years. Therefore, there were more females than males in this study.

This paper reported 56.8 percent of respondents in married category, and 43.2 percent as single as their marital status. Among male respondents, almost two third of them $(66.12 \%)$ were married, which was only about half of this percentage (33.88\%) of female respondents in married category. The majority $(80.58 \%)$ of female respondents in this paper was in single category in marital status (Table 03). This is simply because they are usually older single mother and single older women who are not married (Band-Winterstein et al., 2014). On average, women live longer than men (United Nation, 2019), thus there are many older women in any community.

Table 03: Backgrounds of Poor Vulnerable Respondents by Sex Disaggregation ( $n=322$ )

\begin{tabular}{|c|c|c|c|c|c|c|c|}
\hline \multirow{2}{*}{\multicolumn{2}{|c|}{ Socio Demographic Variable }} & \multicolumn{2}{|c|}{ Male } & \multicolumn{2}{|c|}{ Female } & \multicolumn{2}{|c|}{ Total } \\
\hline & & $n$ & $\%$ & $n$ & $\%$ & $n$ & $\%$ \\
\hline \multirow{4}{*}{ Zone } & Northern & 41 & 47.67 & 45 & 52.33 & 86 & 26.7 \\
\hline & Eastern & 35 & 45.45 & 42 & 54.55 & 77 & 23.9 \\
\hline & Middle & 31 & 42.47 & 42 & 57.53 & 73 & 22.7 \\
\hline & Southern & 41 & 47.67 & 45 & 52.33 & 86 & 26.7 \\
\hline \multirow{4}{*}{ Marital Status } & Total & 148 & 45.96 & 174 & 54.04 & 322 & 100 \\
\hline & Single & 27 & 19.42 & 112 & 80.58 & 139 & 43.2 \\
\hline & Married & 121 & 66.12 & 62 & 33.88 & 183 & 56.8 \\
\hline & Total & 148 & 45.96 & 174 & 54.04 & 322 & 100 \\
\hline \multirow{3}{*}{$\begin{array}{l}\text { Academic } \\
\text { Background }\end{array}$} & $\begin{array}{l}\text { No schooling/ } \\
\text { primary school }\end{array}$ & 87 & 44.16 & 110 & 55.84 & 197 & 61.2 \\
\hline & Secondary/tertiary & 61 & 48.80 & 64 & 51.20 & 125 & 38.8 \\
\hline & Total & 148 & 45.96 & 174 & 54.04 & 322 & 100 \\
\hline \multirow{2}{*}{ Age (2020) } & Mean & \multicolumn{2}{|c|}{65.53} & \multicolumn{2}{|c|}{65.55} & \multicolumn{2}{|c|}{65.54} \\
\hline & SD & \multicolumn{2}{|c|}{14.45} & \multicolumn{2}{|c|}{13.83} & \multicolumn{2}{|c|}{14.096} \\
\hline Household & Mean & \multicolumn{2}{|c|}{1059.39} & \multicolumn{2}{|c|}{927.70} & \multicolumn{2}{|c|}{988} \\
\hline Income (RM) & SD & \multicolumn{2}{|c|}{605.01} & \multicolumn{2}{|c|}{614.25} & \multicolumn{2}{|c|}{612} \\
\hline
\end{tabular}

Note: RM2208=USD532.34

The academic background was divided into two - low academic background refers to not schooling and primary level of education, while high academic background refers to secondary and tertiary academic background. These two academic backgrounds are following Zainalaludin et al (2020). Among low academic background categories, the majority $(55.84 \%)$ of females and 44.16 percent of male respondents had low academic background. Among high background categories, the majority (51.2\%) of females and 48.8 percent of male respondents had high academic background (Table 03). These findings are supported by Zainalaludin (2012) that rural community is often associated with the low academic backgrounds, and moreover in fisheries community (Wahab, 2015), which due to poor education services (Arba et al., 2010), lack of various resources at rural areas (World Bank, 2010) and remote geographical area (Nagaraj et al., 2017).

The mean age of the male respondents was 65.53 years old ( $S D=14.45$ years old), which was almost equal to the mean age of the female respondents, which was 65.55 years old (SD 
=13.83 years old). According to Khazanah Research Institute (2015) United Nation (2009), these mean ages are old ages (Table 03). This study may conclude the poor and vulnerable respondents in the fisheries community are at the mean age of older people. Zain et al (2018) found that fishermen in fisheries community are generally older i.e. above 45 years old, and from poor families. This may also be due to the fact that young people migrate to urban areas for better careers, leaving older people in rural areas (Wan \& Ismail, 2014).

The mean household income of female respondents = RM927.70 (USD224) (SD=RM614.25 (USD148)) which was lower than the mean household income of the male respondents = RM1059.39 (USD255.37), SD=RM605.01 (USD145.84) (Table 03). These findings are supported by many studies that rural women are poorer than rural men (Zain et al., 2018; DOSM, 2017; HLPE, 2014; Zainalaludin, 2010). The mean household income for both male and female respondents in this study was lower than Malaysia PLI (2019) which was RM2208, (USD532.34) per month. Thus, the vulnerable community members in freshwater aquaculture community are concluded as the poor community in this paper; and the vulnerable women are poorer than the vulnerable men. Globally, the fisheries community members are always associated with poverty (Solaymani \& Kari, 2014). Moreover, if they are vulnerable women, the gender gap in income may be due to the masculinity of FAES activities (Sataporvanit, 2018; Cliffe \& Akinrotimi, 2013), where the feminine women have the disadvantages to earn income (Ogunlela \& Mukhtar, 2009; William, 2008).

Through RO1, this paper concludes, the majority of vulnerable community members are female. Though the respondents were sampled equally between males and females, because of the less population of vulnerable males in any freshwater FAES aquaculture community, therefore the community leaders replaced the male with female respondents. In this paper, vulnerable males are majority married, slightly younger than female and from households that earn more income than the females' households. On average, the male respondents in this paper earn slightly lower income as compared to female respondents. Nevertheless, female respondents are majority single, slightly older and from households which earn lower income than the male respondents.

\section{Distributions of Respondents by Vulnerability Types and Sex Disaggregation}

Table 04 presents the findings on RO2 (to identify the distributions of respondents by types of vulnerability and by sex disaggregation). Table 04 shows the highest percentage $(32.85 \%)$ of the respondents that are from Older Person Type of Vulnerability, then followed by Serious Disease (30.12\%), Single Parent (17.3\%), Caretaker (10.51\%), Living Alone (5.62\%) and Handicapped (3.6\%). The distributions of the respondents under Older Person and Serious Disease Vulnerability Types were almost equal, and on average, this paper may support the conclusion that older person may be prone to serious diseases (Backers et al., 2008). 
INTERNATIONAL JOURNAL OF ACADEMIC RESEARCH IN BUSINESS AND SOCIAL SCIENCES

Vol. 11, No. 12, 2021, E-ISSN: 2222-6990 ๑ 2021 HRMARS

Table 04: Distribution of Respondents by Vulnerability Type and Sex Disaggregation

$(n=322)$

\begin{tabular}{lrrrrrr}
\hline & \multicolumn{2}{c}{ Male } & \multicolumn{3}{c}{ Female } & \multicolumn{2}{c}{ Total } \\
\cline { 2 - 7 } \multicolumn{1}{c}{ Vulnerable Type } & $n$ & $\%$ & $n$ & $\%$ & $n$ & $\%$ \\
\hline Handicapped & 17 & 68.00 & 8 & 32.00 & 25 & 3.60 \\
Single parent & 13 & 10.83 & 107 & 89.17 & 120 & 17.3 \\
Old Person & 105 & 46.05 & 123 & 53.95 & 228 & 32.85 \\
Serious Disease & 94 & 44.98 & 115 & 55.02 & 209 & 30.12 \\
Caretaker & 33 & 45.21 & 40 & 54.79 & 73 & 10.51 \\
Living Alone & 8 & 20.51 & 31 & 79.49 & 39 & 5.62 \\
\hline Total & 265 & 39.14 & 412 & 60.86 & 694 & 100 \\
\hline
\end{tabular}

Note: Multiple response $n=694 ; 100$ percent by row (male + female)

There was a high majority (89.17\%) of single mothers and only 10.83 percent of single fathers under Single Parent. There were more single mothers than single fathers reported in this paper, which supports the scenario that men are involved in high work risk and masculine FAES aquaculture activities. They may face fatal accidents while fishing and leave behind single mothers (Zainalaludin et al., 2017; Cliffe \& Akinrotimi, 2013). Single mothers in this study may be due to divorce with proper documents and separated marriage without legal divorce document (Mulia, 2017; Abd Hamid \& Salleh, 2013). A majority (53.95\%) of female respondents, and a high percentage $(46.05 \%)$ of male respondents in this study were older people (Table 04). There are many older women in the fisheries community may be due to the women living longer than men (United Nation, 2019), and they are older single mothers (Mulia, 2017).

A majority (55.02\%) of female respondents, and a high percentage (44.98\%) of male respondents suffer from Serious Disease Type of Vulnerability (Table 04). Many females suffer from serious diseases may be due to the lack of physical activities (Ali \& Isa, 1995), and malnutrition among females in poor household (Ihab et al., 2013), because females in poor household always consume less food than the male family members. In addition, female may be vulnerable to disease due to three obstacles which are structural, financial and personal/cultural obstacles (Chiang et al., 2013). These obstacles may stop them from seeing the doctor (Syed et al., 2013; Chiang et al., 2013), and to get the proper health care services. In addition, there are also poor service facilities at rural areas (Ismail \& Ariffin, 2021; Naing, 2006).

There was a majority (54.79\%) of female respondents, and only 45.21 percent of male respondents who were from the Caretaker Type of Vulnerability (Table 04). Taking care of the family members are women gender roles in the household, as for example, as the caretakers for older, children and bedridden or family members suffering from epilepsy (Hirschman, 2016, Sullivan \& Miller, 2015; Abdullah et al., 2008). Nevertheless, many male respondents also claimed that they are the caretakers because some such activities involve masculine tasks such as lifting the bedridden patient. Both husband and wife may get involved together in taking care of the vulnerable family members, except the Single Parent Vulnerability Type.

A high majority (79.49\%) of female respondents suffer from Living Alone Vulnerable Type while only 20.51 percent of the male respondents (Table 04). Again, this may be due to the 
longer life expectancy of female than male globally in which there is a high risk of women to live alone at their old age (United Nation, 2019; DOSM, 2019; Hamid, 2015). Females from this category may be widower (Zainalaludin et al., 2017), or divorcees who remain single until their old age (De Vaus \& Qu, 2015). Those who live alone may be lonely and in long term they may suffer from various diseases. They need extra care through programs and community care such as regular visit by volunteers and doctors to monitor their health status as well as to talk to them.

A high majority (68\%) of the male respondents suffer from Handicapped Type of Vulnerability, then only 32 percent of female respondents. These distributions may be due to the males' direct involvement in masculine FAES activities. They might be involved in accidents while fishing (Zainalaludin et al., 2017) which caused them to become disabled or handicapped (Frantzeskou et al., 2012). Among female respondents, they may be suffering from the Handicapped Type of Vulnerability because of the serious disease that they have. For example, chronic diabetes may cause them to lose their leg (Kalra et al., 2018; WHO, 2016).

In RO2, the percentages in each vulnerability type are presented by sex disaggregation. Through RO2, this paper may conclude descriptively by looking at the number of respondents $(n)$ in Table 04, the vulnerable respondents in this paper are mainly older person ( $n=123$ male; $n=107$ among female). By looking at the highest percentage by the vulnerability type and sex, the highest percentage among men is under the Handicapped Vulnerability Type category, and the highest percentage among females is under Single Parent Vulnerability Type category. These findings may support the literatures on the masculinity of FAES activities, because these activities may involve fishermen in fatal accidents or major accidents in which it may lead to many single mothers and handicapped men in the community respectively.

\section{Best Vulnerability Type that explains Male in Poor Category of Household Income}

This sub-topic presents the findings on part of RO3 (to measure the vulnerability type that predicts the likelihood of the respondents in poor category of household income by sex disaggregation). Thus, two null hypotheses were tested which were HO1 (No type of vulnerability significantly predicts male respondents in poor category of household income in freshwater fisheries community), and $\mathrm{HO} 2$ (No vulnerability type significantly predicts the female respondents in poor category of household income in freshwater fisheries community). This sub topic presents the findings on HO1. BLR Model 1 was used to test HO1 as follows: -

BLR Model $1-\operatorname{Ln} Y_{\text {Poor Male }}=a+b_{1}$ handicapped $+b_{2}$ single parent $+b_{3}$ living alone

Note: male respondent with poor category of household income (income<RM2208 (USD532.34))

BLR Model 1 is fit and significant $(p<0.05)$ to be used to predict male vulnerable respondents in poor category of household income. Thus, $\mathrm{HO} 1$ is rejected. In 39.1 percent variance in the DV can be explained by the IVs (Table 05). Only three types of vulnerability had significant $(p<0.05)$ relationships with the DV and had no multicollinearity with one another, and only two IVs significantly predicted the DV - the Handicapped and Single Parent Type of Vulnerability (Table 05). 
Table 05: Wald Chi Square Statistics Predict Male Vulnerable Respondent in Poor category of Household Income ( $n=322)$

\begin{tabular}{lccrrrr}
\hline $\begin{array}{l}\text { Type of } \\
\text { Vulnerability }\end{array}$ & B & S.E. & Wald & df & Sig. & Exp(B) \\
\hline Handicapped & $\mathbf{1 . 2 8 1}$ & $\mathbf{. 5 5 3}$ & $\mathbf{5 . 3 6 5}$ & $\mathbf{1}$ & $\mathbf{. 0 2 1}$ & $\mathbf{3 . 6 0 0}$ \\
Single Parent & $\mathbf{- 2 . 7 9 5}$ &. $\mathbf{3 4 6}$ & $\mathbf{6 5 . 1 8 7}$ & $\mathbf{1}$ & $\mathbf{. 0 0 0}$ & $\mathbf{0 6 1}$ \\
Living Alone & -.362 & .522 & .481 & 1 & .488 & .696 \\
Constant & .634 & .155 & 16.826 & 1 & .000 & 1.885 \\
\hline
\end{tabular}

Note: Multiple response ( $n=694)$; Significant $(p<0.05)$; Poor Male $=1$; Poor Female $=0$

The Handicapped Type of Vulnerability predicted 3.6 times of the likelihood of male per one likelihood of female respondents in poor category of household income (Table 05). The Single Parent Type of Vulnerability predicted less 93.9 percent of the likelihood of male respondents in poor category of household income. As a conclusion, only the handicapped male may be in poor category of household income, and single father almost 100 percent less of the likelihood to be in poor category of household income in freshwater community.

Someone suffering the Handicapped Type of Vulnerability is usually marginalized (Humphrey, 2016) in any economic sector as well as in FAES. According to Emmett and Alant (2006), a handicapped male can still support the household with a very minimum capacity to earn the income in fisheries community. Nevertheless, they have less power to influence the employer to accept them as worker (Bonaccio et al., 2019). Moreover, in a masculine economic sector where handicapped individual usually receives a low pay and is often unemployed (WHO, 2011). Due to this, the handicapped group had been included as a target in 2030 Agenda for Sustainable Development (Blind, 2019; United Nation, 2018) with respect to poverty eradication (SDG 1), reduce inequality (SDG 10) and to achieve food security (SDG 2) among the handicapped.

\section{Best Vulnerability Type that Explains Female in Poor Category of Household Income}

HO2 (No vulnerability type significantly predicts the female respondents in poor category of household income in freshwater fisheries community) was tested through the following model: -

BLR Model $2-\operatorname{Ln} Y_{\text {Poor Female }}=a+b 1_{1}$ handicapped $+b_{2}$ single parent $+b_{3}$ living alone

Note: female respondent with poor category of household income (income $<$ RM2208 (USD532.34))

Model 2 is fit and significant $(p<0.05)$ to predict the female over the male respondents in poor category of household income. Thus, $\mathrm{HO} 2$ is rejected. 38.9 percent variance in DV can be explained by the Handicapped and Single Parent of Vulnerability Types in Model 2 (Table 06). Only three types of vulnerability had significant relationships respectively with the DV, and no multicollinearity between the three IVs. Only two IVs significantly predicted the DV which were the Handicapped and Single Parent Types of Vulnerability (Table 06). 
INTERNATIONAL JOURNAL OF ACADEMIC RESEARCH IN BUSINESS AND SOCIAL SCIENCES

Vol. 11, No. 12, 2021, E-ISSN: 2222-6990 ๑ 2021 HRMARS

Table 06: Wald Chi Square Statistics Predict Female Vulnerable Respondent in Poor category of Household Income (Model 2) ( $n=322$ )

\begin{tabular}{lcccccc}
\hline & B & S.E. & Wald & df & Sig. & Exp(B) \\
\hline Handicapped & $\mathbf{- 1 . 2 9 0}$ & .552 & $\mathbf{5 . 4 6 3}$ & $\mathbf{1}$ & .019 & .275 \\
Living Alone & .354 & .522 & .459 & 1 & .498 & 1.424 \\
Single Parent & $\mathbf{2 . 7 8 2}$ & .347 & $\mathbf{6 4 . 4 4 3}$ & $\mathbf{1}$ & .000 & $\mathbf{1 6 . 1 4 5}$ \\
Constant & -.617 & .155 & 15.857 & 1 & .000 & .539 \\
\hline
\end{tabular}

Note: Multiple response ( $n=694)$; Significant $(p<0.05)$

Table 06 shows Single Parent Vulnerability Type in which single mother predicted 16.15 times of the likelihood upon single fathers to be in poor category of household income. The Handicapped Type of Vulnerability predicted less $72.5 \%$ of the likelihood of female upon male respondents in poor category of household income. From these findings, it can be concluded that among female respondents in fisheries community, single mothers are strongly associated with poverty incidence. Compared to male respondents in Table 05 for Handicapped Type of Vulnerability, it positively predicted male and negatively predicted female respondents in poor category of household income.

According to Masud et al (2015), women will only be acknowledged as the household head after losing their husband or after getting divorced. Nevertheless, in any economic sectors, single mothers usually gain lower income than single fathers (Stack \& Meredith, 2018; Kramer et al., 2016; Hilton \& Kopera-Frye, 2006). In masculine FAES, single mothers in freshwater community are usually old single mothers, thus they have less ability to work. Many rural single mothers are also highly dependent on their ex-husband through the alimony income (Wahab et al., 2018; Holvoet \& Chiambeng, 2011). Therefore, they are highly vulnerable to poverty (Masud \& Zainalaludin, 2018; McGuire, 2015).

\section{Conclusion}

The major conclusion of this study is, besides poverty, the vulnerability in fisheries community involves gender-related issues. FAES is a masculine economic sector which is more suitable for men. Thus, female and vulnerable individuals may not be able to work directly in FAES, and they are usually associated with poverty incidences in fisheries community. The vulnerable respondents in this paper are poor males and females with low academic background and older people on average. In this paper, the Handicapped and Single Parent Type of Vulnerability had significantly predicted male and female respondents respectively in the poor category of household income. The Handicapped Type of Vulnerability had positively predicted male and negatively predicted female in the poor category of household income. While Single Parent Type of Vulnerability had negatively predicted male and positively predicted female in the poor category of household income.

Policy and program development, especially in poverty eradication in freshwater fisheries community should focus on the elderly, handicapped men and single mothers. They need less masculine economic sector in masculine FAES, for example the eco-tourism activities, homestay, food processing and catering services. This paper also concludes that vulnerability involves gender and poverty-related issues, in which vulnerable women are poorer than vulnerable men. Future studies should focus on other masculine communities, for example, agriculture communities and brackishwater fisheries community. 


\section{Acknowledgement}

The study reported in this paper was granted by Putra Grant Scheme-IPS (GP-IPS), through a research titled "Relationship between Gender and Vulnerable Types towards Life Wellbeing among Poor Freshwater Aquaculture and Fisheries Community Members in Peninsular Malaysia" (Grant Number: GP-IPS/2018/9603700; VOT No. 9603700).

\section{References}

Abd Hamid, S. R., \& Salleh, S. (2013). Exploring single parenting process in Malaysia: Issues and coping strategies. Procedia-Social and Behavioral Sciences, 84, 1154-1159. doi: 10.1016/j.sbspro.2013.06.718

Abdullah, K., Noor, N. M., \& Wok, S. (2008). The perceptions of women's roles and progress: A study of Malay women. Social Indicators Research,89(3), 439-455. DOI 10.1007/s11205-008-9242-7

Ahmad, A. T., Salim, K., Chee, P. E., Isa, M. M., \& Lim, C. F. (2003). An overview of the socioeconomic status of fisheries in Malaysia.

Ali, O., \& Isa, Z. (1995). Nutritional status of women and children in Malaysian rural populations. Asia Pacific Journal of Clinical Nutrition, 4, 319-324. Retrievr from https://apjcn.nhri.org.tw/SERVER/APJCN/4/3/319.pdf

Allison, E. H., Horemans, B., \& Béné, C. (2006). 'Vulnerability Reduction and Social Inclusion: Strategies for Reducing Poverty among Small-scale Fisherfolk'. Paper presented at the Wetlands, Water and Livelihoods Workshops, Wetland International, St. Lucia, South Africa, 30 January-2 February.

Asok, D. A., \& Saranya, R. (2016). A study on income and expenditure pattern of fishermen in veerapandianpattinam area. International Journal of Multidisciplinary Research and Development, 3(10), 19-22.

Azer, I., Hamzah, H. C., Mohamad, S. A., \& Abdullah, H. (2016). Contribution of economic sectors to Malaysian GDP. In Regional Conference on Science, Technology and Social Sciences (RCSTSS 2014) (pp. 183-189). Springer, Singapore. DOI: 10.1007/978-981-101458-1_17

Band-Winterstein, T., \& Manchik-Rimon, C. (2014). The experience of being an old nevermarried single: A life course perspective. The International Journal of Aging and Human Development, 78(4), 379-401. doi: http://dx.doi.org/10.2190/AG.78.4.d

Bertolini, P. (2019). Overview of income and non-income rural poverty in developed countries. Presentation. Retrieved, 5, 2020.

Blind, P. K. (2019). Humanitarian SDGs: Interlinking the 2030 Agenda for Sustainable Development with the Agenda for Humanity.

Bolderson, H. (2007). Exclusion of vulnerable groups from equal access to social security. In Social Security as a Human Right (pp. 129-143). Springer, Berlin, Heidelberg. ISSN 16171497

Bonaccio, S., Connelly, C. E., Gellatly, I. R., Jetha, A., \& Ginis, K. A. M. (2019). The participation of people with disabilities in the workplace across the employment cycle: Employer concerns and research evidence. Journal of Business and Psychology, 1-24. DOI: 10.1007/s10869-018-9602-5

Bradshaw, S., Chant, S., \& Linneker, B. (2019). Challenges and changes in gendered poverty: the feminization, de-feminization, and re-feminization of poverty in Latin America. Feminist Economics, 25(1), 119-144. doi:10.1080/13545701.2018.1529417 
Casmiwati, D., Ibrahim, A. Z., \& Bakar, A. H. (2019). Strategy of fishermen Surabaya city, Indonesia to maintain their livelihood. European Journal of Research, 3, 23-28. DOI:10.26739/2521-3253-2019-3-4

Chiang, C., Labeeb, S. A., Higuchi, M., Mohamed, A. G., \& Aoyama, A. (2013). Barriers to the use of basic health services among women in rural southern Egypt (Upper Egypt). Nagoya Journal of Medical Science, 75(3-4), 225.

Chintey, R. M., \& Chintey, B. (2014). Women and children as vulnerable groups in India: their health and human rights. IOSR Journal of Humanities and Social Science (IOSR-JHSS), 19 (6), 01-04.

Chulu, J. (2015). A Feminist Perspective that Poverty is Gendered: Do Women Have Lesser Access to Resources in Comparison with Men?. Available at SSRN 2663381.

Cliffe, P. T., \& Akinrotimi, O. A. (2013). The role of women in fishery activities in some coastal communities of Rivers State, Nigeria. In: 28th Annual Conference of the Fisheries Society of Nigeria (FISON), 25-29 Nov 2013, Abuja, Nigeria, pp. 397-401.

Cox, J. (1998). Poverty in rural areas: is more hidden but no less real than in urban areas. doi: 10.1136/bmj.316.7133.722

De Vaus, D. A., \& Qu, L. (2015). Living alone and personal wellbeing. Australian Institute of Family Studies.

Department of Fisheries. (2019). Annual Fisheries Statistic 2019. Retrieve from https://www.dof.gov.my/index.php/pages/view/82

Department of Statistic Malaysia. (2019). Report on selected Agriculture Indicators, Malaysia 2019

Dommaraju, P., \& Jones, G. W. (2011). Divorce trends in Asia. Asian Journal of Social Science, 39, 725-750. https://doi.org/10.1163/156853111X619201

DOSM. (2017). Press Release Gross Domestic Product Second Quarter 2017. Statistic Malaysia 2015, 7-9.

DOSM. (2020). Household Income \& Basic Amenities Survey Report 2019. Press Release

Eagly, A. H. (1987). Reporting sex differences. https://doi.org/10.1037/0003-066X.42.7.755

Eagly, A. H., Wood, W., \& Diekman, A. B. (2000). Social role theory of sex differences and similarities: A current appraisal. The Developmental Social Psychology of Gender, 12, 174.

Economic Planning Unit (EPU), 2014. Household Income and Poverty

Emmett, T., \& Alant, E. (2006). Women and disability: exploring the interface of multiple disadvantage. Development Southern Africa, 23(4), 445-460. https://doi.org/10.1080/03768350600927144

Eriksen, S. H., \& O'brien, K. (2007). Vulnerability, poverty and the need for sustainable adaptation measures. Climate Policy, 7(4), 337-352.

DOI:10.1080/14693062.2007.9685660

FAO. (2018). The State of World Fisheries and Aquaculture 2018 - Meeting the sustainable development goals. Rome. Licence: CC BY-NC-SA 3.0 IGO

Feldman, R. M., \& Stall, S. (2004). The dignity of resistance: women residents' activism in Chicago public housing. Cambridge University

Press. https://doi.org/10.1017/CBO9780511734977

Frantzeskou, E., Kastania, A. N., Riza, E., Jensen, O. C., \& Linos, A. (2012). Risk factors for fishermen's health and safety in Greece. International Maritime Health, 63(3), 155-161. ISSN 1641-9251 
Frongillo, E. A., Nguyen, H. T., Smith, M. D., \& Coleman-Jensen, A. (2019). Food Insecurity Is More Strongly Associated with Poor Subjective Well-Being in More-Developed Countries than in Less-Developed Countries. The Journal of Nutrition, 149(2), 330-335. DOI: $10.1093 / \mathrm{jn} / \mathrm{nxy} 261$

Fujii, T. (2016). Concepts and measurement of vulnerability to poverty and other issues: A review of literature. In The Asian 'Poverty Miracle'. Edward Elgar Publishing. Available at: https://ink.library.smu.edu.sg/soe_research/1939

Gallardo, M. (2018). Identifying vulnerability to poverty: A critical survey. Journal of Economic Surveys, 32(4), 1074-1105. https://doi.org/10.1111/joes.12216

Gamblin, M. D. (2017). Ending US Hunger and Poverty by Focusing on Communities Where it's Most Likely. Bread for the World Institute.

Giron-Nava, A., Lam, V. W., Aburto-Oropeza, O., Cheung, W. W., Halpern, B. S., Sumaila, U. R., \& Cisneros-Montemayor, A. M. (2021). Sustainable fisheries are essential but not enough to ensure well-being for the world's fishers. Fish and Fisheries. https://doi.org/10.1111/faf.12552

Hamid, T. A. (2015). Population ageing in Malaysia: A mosaic of issues, challenges and prospects. Serdang: Universiti Putra Malaysia Press.

Hartline-Grafton, H., \& Dean, O. (2017). The impact of poverty, food insecurity, and poor nutrition on health and well-being. Washington, DC: Food Research \& Action Center. Available at $n$ www.frac.org

Hilhorst, D. J. M., \& Bankoff, G. E. A. (2004). Introduction: mapping vulnerability.

Hilton, J. M., \& Kopera-Frye, K. (2006). Loss and depression in cohabiting and noncohabiting custodial single parents. The Family Journal, 14(1), 28-40. https://doi.org/10.1177/1066480705282053

Hirschman, C. (2016). Gender, the status of women, and family structure in Malaysia. Malaysian Journal of Economic Studies, 53(1), 33-50. ISSN 1511-4554

HLPE. 2014. Sustainable fisheries and aquaculture for food security and nutrition. A report by the High Level Panel of Experts on Food Security and Nutrition of the Committee on World Food Security, Rome 2014.

Holvoet, K., \& Chiambeng, G. Y. (2011). Vulnerability of small-scale marine fishing communities to HIV/AIDS in Cameroon. University of Greenwich.

Humphrey, M. (2016). The intersectionality of poverty, disability, and gender as a framework to understand violence against women with disabilities: a case study of South Africa. International Development, Community and Environment (IDCE). 36

Hussin, F., \& Yik, S. Y. (2012). The contribution of economic sectors to economic growth: the cases of China and india. Research in Applied Economics, 4(4), 38-53. DOI: $10.5296 /$ rae.v4i4.2879

Ihab, A. N., Rohana, A. J., Manan, W. W., Suriati, W. W., Zalilah, M. S., \& Rusli, A. M. (2013). The coexistence of dual form of malnutrition in a sample of rural Malaysia. International Journal of Preventive Medicine, 4(6), 690

International Labour Office. (2013). Caught at sea: forced labour and trafficking in fisheries. International Labour Office

Islam, M. S. (2008). From sea to shrimp processing factories in Bangladesh: gender and employment at the bottom of a global commodity chain. Journal of South Asian Development, 3(2), 211-236. DOI: 10.1177/097317410800300202 
Kalra, S., Jena, B. N., \& Yeravdekar, R. (2018). Emotional and psychological needs of people with diabetes. Indian Journal of Endocrinology and Metabolism, 22(5), 696. DOI:10.4103/ijem.IJEM_579_17

Kaufmann, C. (2008). ILO, Declaration on Social Justice for a Fair Globalization. ILO.

Khazanah Research Institute. 2015. Population Ageing Can We "Live Long and Prosper"? Kuala Lumpur: Khazanah Research Institute. License: Creative Commons Attribution CC BY 3.0

Kramer, K. Z., Myhra, L. L., Zuiker, V. S., \& Bauer, J. W. (2016). Comparison of poverty and income disparity of single mothers and fathers across three decades: 19902010. Gender Issues, 33(1), 22-41. DOI:10.13140/RG.2.1.3478.9600

Krejcie, R. V., \& Morgan, D. W. (1970). Determining Sample Size for Research Activities. Educational.

Kumar, A. (2018) Major concerning issues and challenges for women health: An Interpretation. Review of Research Journal, 7(11). Available online at www.lbp.world

Leavy, J., \& Hossain, N. (2014). Who wants to farm? Youth aspirations, opportunities and rising food prices.IDS Working Papers, 2014(439), 1-44. DOI:10.1111/j.20400209.2014.00439.x

Lentisco, A., \& Lee, R. U. (2015). A review of women's access to fish in small-scale fisheries. FAO Fisheries and Aquaculture Circular, (C1098), I.

$\mathrm{Li}, \mathrm{Q}$. (2020). Mothers left without a man: Poverty and single parenthood in China. Social Inclusion, 8(2), 114-122. DOI: 10.17645/si.v8i2.2678

Lim, L. L., \& Kua, E. H. (2011). Living alone, loneliness, and psychological well-being of older persons in Singapore. Current Gerontology and Geriatrics Research, 2011. DOI: $10.1155 / 2011 / 673181$

Masud, J., \& Zainalaludin, Z. (2018). Gender and Poverty among Elderly in Malaysia. Archives of Business Research, 6(12), 242-251. DOI:10.14738/abr.612.5800

Masud, J., Hamid, T. A., \& Haron, S. A. (2015). Measuring poverty among elderly Malaysians. Asian Journal for Poverty Studies (AJPS), 1(1).

McGuire, S. (2015). FAO, IFAD, and WFP. The state of food insecurity in the world 2015: meeting the 2015 international hunger targets: taking stock of uneven progress. Rome: $F A O, 2015$.

McIntyre, P. B., Liermann, C. A. R., \& Revenga, C. (2016). Linking freshwater fishery management to global food security and biodiversity conservation. Proceedings of the National Academy of Sciences, 113(45), 12880-12885. DOI: 10.1073/pnas.1521540113

McKenzie, H., \& Cook, K. (2008). The Australian child support scheme as it relates to single mothers: Historical development and international comparisons. In 10th Australian Institute of Family Studies Conference. DOI:10.1080/13229400.2015.1011769

Minkler, M., \& Stone, R. (1985). The feminization of poverty and older women. The Gerontologist, 25(4), 351-357. https://doi.org/10.1093/geront/25.4.351

Monchuk, V. (2013). Reducing poverty and investing in people: The new role of safety nets in Africa. The World Bank.

Mulia, D. S. (2017). Survival Strategies of Single Mothers among Indigenous Ethnics in Rural Areas: Case Study in Kota Belud, Sabah. Jurnal Kinabalu.

Nagaraj, S., Lee, K. H., Goh, K. L., \& Tey, N. P. (2017). Malaysian adolescents not in school: The nexus of education, work and gender. Malaysian Journal of Economic Studies, 53(1), 87113.

Nair, S., \& Sagaran, S. (2017). Poverty in Malaysia: Need for a paradigm shift. Institutions and Economies, 95-123. 
National Wellness Institute. (1976). The Six Dimension of Wellness Model.

https://cdn.ymaws.com/www.nationalwellness.org/resource/resmgr/docs/sixdimensi onsfactsheet.pdf

Nazri, N. A., Zainuddin, A., Abd Samad, S., \& Alam, S. (2019). A review on the prevalence of women poverty in Malaysia. $7^{\text {th }}$ International Conference on Public Policy and Social Science. $18^{\text {th }}-19^{\text {th }}$ November 2019.

Ngarava, S., Zhou, L., \& Monde, N. (2019). Gendered water insecurity: A structural equation approach for female headed households in south africa. Water, 11(12), 2491. https://doi.org/10.3390/w11122491

Oginni, A., Ahonsi, B., \& Ukwuije, F. (2013). Are female-headed households typically poorer than male-headed households in Nigeria? The Journal of Socio-Economics, 45,132-137. http://dx.doi.org/10.1016/j.socec.2013.04.010

Ogunlela, Y. I., \& Mukhtar, A. A. (2009). Gender issues in agriculture and rural development in Nigeria: The role of women. Humanity \& Social Sciences Journal, 4(1), 19-30.

Osman, M. M., Bakri, N. I. M., Bachok, S., Ibrahim, M., \& Mohamed, M. Z. (2015). Assessing social welfare department service delivery system towards vulnerable and disadvantages group in Malaysia: case study of Perak. Procedia Environmental Sciences, 28, 418-426. doi: 10.1016/j.proenv.2015.07.051

Paweenawat, S. W., \& McNown, R. (2014). The determinants of income inequality in Thailand: A synthetic cohort analysis. Journal of Asian Economics, 31, 10-21. DOI: 10.1016/j.asieco.2014.02.001

Qaisrani, A., Umar, M. A., Siyal, G. E. A., \& Salik, K. M. (2018). What defines livelihood vulnerability in rural semi-arid areas? Evidence from Pakistan. Earth Systems and Environment, 2(3), 455-475. https://doi.org/10.1007/s41748-018-0059-5

Reinharz, S. (1993). Neglected voices and excessive demands in feminist research. Qualitative Sociology, 16(1), 69-76.

Ringbäck-Weitoft, G. (2001). Chapter 9. Social Differences, Vulnerability and IIIhealth. Scandinavian Journal of Public Health, 29(58), 199-218. https://doi.org/10.1177/14034948010290032601

Rojas, M. (2015). Poverty and people's wellbeing. In Global handbook of quality of life (pp. 317-350). Springer, Dordrecht. DOI 10.1007/978-94-017-9178-6

Sadan, E. (2004). Empowerment and community planning. https://doi.org/10.1093/acrefore/9780199975839.013.1164

Salleh, M. R. (2008). Life event, stress and illness. The Malaysian Journal of Medical Sciences: MJMS, 15(4), 9.

Samah, B. A., Shaffril, H. A. M., Hassan, M. S., Hassan, M. A., \& Ismail, N. (2009). Contribution of information and communication technology in increasing agro-based entrepreneurs productivity in Malaysia. Journal of Agriculture and Social Sciences, 5(3), 93-98.

Satapornvanit, A. N. (2018). The importance of gender in fisheries: The USAID Oceans experience. Fish for the People, 16(2), 9-13.

Schulz, R., Eden, J., \& National Academies of Sciences, Engineering, and Medicine. (2016). Family caregiving roles and impacts. In Families caring for an aging America. National Academies Press (US). doi: 10.17226/23606.

Seligman, H. K., Laraia, B. A., \& Kushel, M. B. (2010). Food insecurity is associated with chronic disease among low-income NHANES participants. The Journal of nutrition, 140(2), 304310. doi: 10.3945/jn.109.112573 
Shah, V., \& Shah, P. (2016). Work-Family Balance-A Challenge for A Women. Indian Journal of Technical Education (IJTE). Special Issue for ICWSTCSC-2016.

Singh, P., Rahman, A. A., \& Hoon, T. S. (2010). Languages and Mathematics Achievements among Rural and Urban Primary Four Pupils: A Malaysian Experience. Journal of Science and Mathematics Education in Southeast Asia, 33(1), 65-85.

Siswanto, A., Ridho, M. R., \& Wildayana, E. (2021). Characteristics and Roles of Fisherwomen During The Fishing/Non-Fishing Season: A Case Study in Banyuasin Regency. HISPISI: Himpunan Sarjana IImu-IImu Pengetahuan Sosial Indonesia, 1(1), 335-345.

Solaymani, S., \& Kari, F. (2014). Poverty evaluation in the Malaysian fishery community. Ocean \& Coastal Management, 95, 165-175. http://dx.doi.org/10.1016/j.ocecoaman.2014.04.017

Sornkliang, J., Tiaye, R., Yenpoeng, T., Kaewtankam, V., \& Pholcharoen, J. (2018). Recognizing gender roles in the fisheries value chain: local fishing communities of Thailand in focus. Fish for the People, 16(2), 14-19.

Stack, R. J., \& Meredith, A. (2018). The impact of financial hardship on single parents: An exploration of the journey from social distress to seeking help. Journal of Family and Economic Issues, 39(2), 233-242. DOI 10.1007/s10834-017-9551-6

Stergiou-Kita, M., Mansfield, E., Bezo, R., Colantonio, A., Garritano, E., Lafrance, M., ... \& Theberge, N. (2015). Danger zone: Men, masculinity and occupational health and safety in high risk occupations. Safety Science, 80, 213-220. doi:10.1016/j.ssci.2015.07.029

Sullivan, A. B., \& Miller, D. (2015). Who is taking care of the caregiver?. Journal of Patient Experience, 2(1), 7-12.

Syed, S. T., Gerber, B. S., \& Sharp, L. K. (2013). Traveling towards disease: transportation barriers to health care access. Journal of Community Health, 38(5), 976-993. doi: 10.1007/s10900-013-9681-1

Techane, M. G. (2017). Economic Equality and Female Marginalisation in the SDGs Era: Reflections on Economic Rights of Women in Africa. Peace Human Rights Governance, 1(3). DOI:10.14658/pupj-phrg-2017-3-2

Teh, L. C., \& Pauly, D. (2018). Who brings in the fish? The relative contribution of small-scale and industrial fisheries to food security in Southeast Asia. Frontiers in Marine Science, 5, 44. https://doi.org/10.3389/fmars.2018.00044

Thapa, D. K., Visentin, D., Kornhaber, R., \& Cleary, M. (2018). Migration of adult children and mental health of older parents 'left behind': An integrative review. PloS one, 13(10), e0205665. doi: 10.1371/journal.pone.0205665

Tidwell, J. H., \& Allan, G. L. (2015). Ecological and economic impacts and contributions of fish farming and capture fisheries. doi: 10.1093/embo-reports/kve236

United Nation. (2009). World population ageing 2009. Department of Economic and Social Affairs: Population Division, 129.

United Nation. (2018). The 17 Goals. https://sdgs.un.org/goals

United Nation. (2015). Transforming our world: the 2030 Agenda for Sustainable Development. New York, USA.

United Nations. (2015). The World's Women 2015: Trends and Statistics. New York: United Nations, Department of Economic and Social Affairs, Statistics Division. Sales No. E.15.XVII.8.

United Nations. (2019). World Population Ageing 2019: Highlights (ST/ESA/SER.A/430). 
Veeran, V. (2000). Feminization of poverty. In Women's Symposium of International Association of Schools of Social Work in Montreal, Canada. DOI:10.13140/2.1.3039.2000

Verschelden, C. (2017). Bandwidth recovery: Helping students reclaim cognitive resources lost to poverty, racism, and social marginalization. Stylus Publishing, LLC.

Wahab, M. A. A., Ghani, N. A., \& Yusof, H. (2018). Initial Discussion on the Past Studies of WellBeing. International Journal of Academic Research in Business and Social Sciences, 8(5), 74-86. DOI: 10.6007/IJARBSS/v8-i5/4086

Wahab, Z. A. (2015). Kesejahteraan Sosial Komuniti Pesisir : Kajian Kes di Kampung Nelayan Kandis Bachok dan Kampung Baru Nelayan Tumpat Kelantan. Tesis PhD, Universiti Malaysia Kelantan

Wan Ahmad, W. I., \& Ismail, Z. (2014). Some demographic aspects of Chinese population in Malaysia. World Applied Sciences Journal, 30(7), 923-926. DOI: 10.5829/idosi.wasj.2014.30.07.14086

WHO (2011). Geneva; and, OECD, Sickness, Disability and Work: Breaking the Barriers, A Synthesis of Findings across OECD Countries, 2010, France; ILO: Rural Policy Briefs, Empowering People with Disabilities for Rural Development, 2011, Geneva.

Williams, M. J. (2008). Why look at fisheries through a gender lens?. Development, 51(2), 180185.

Wood, W., \& Eagly, A. H. (2012). Biosocial construction of sex differences and similarities in behavior. In Advances in experimental social psychology (Vol. 46, pp. 55-123). Academic Press.

World Bank. (2010). World Development Report 2010: Development and Climate Change. New York: The World Bank.

World Health Organization. (2008). Older persons in emergencies: an active ageing perspective. Geneva: World Health Organization.

World Health Organization. (2016). World health statistics 2016: monitoring health for the SDGs sustainable development goals. World Health Organization.

Wrigley, A., \& Dawson, A. (2016). Vulnerability and marginalized populations. In Public Health Ethics: Cases Spanning the Globe (pp. 203-240). Springer, Cham. DOI 10.1007/978-3319-23847-0

Yang, Y. (2018). Aging in community and local NGOs: Empowering marginalized older women in South Korea. Journal of Women \& Aging, 30(4),344-362. DOI: 10.1080/08952841.2017.1392066

Yeo, B. H. (2007). Fisher profiles and perceptions of sea turtle-fishery interactions: case study of East Coast Peninsular Malaysia (Vol. 6). WorldFish.

Yusri, A., \& Ramli, Z. (2016). The Study towards the Traditional Fisherman Survival Mechanism in Facing Famine Season in Meskom Village of Bengkalis Regency, Indonesia. Mediterranean Journal of Social Sciences, 7(4), 363-363. DOI: 10.36941/mjss

Zain, R. M., Kamarudin, M. K. A., \& Saad, M. H. M. (2018). Assessment of Quality Of Life on Fishermen Community in Kuala Terengganu, Malaysia: A Review. International Journal of Academic Research in Business and Social Sciences, 8(10), 640-650. DOI: 10.6007/IJARBSS/v8-i10/4770

Zain, Z. M., Khalid, N. S. M., Nurudin, S. M., \& Onimisi, T. (2021). Poverty Alleviation Policies in Malaysia and Nigeria: A review. Environment-Behaviour Proceedings Journal, 6(16), 239-246. DOI: https://doi.org/10.21834/ebpj.v6i16.2694 
Zainalaludin, (2010). Indicators of micro enterprise development for small family business in rural Peninsular Malaysia, Unpublished PhD Thesis.

Zainalaludin, Z. (2012). Scaling up rural micro enterprise: Profiles of owners in Peninsular Malaysia. Pertanika Journal (Social Science and Humanities), 20(4), 1049-1064.

Zainalaludin, Z., Jamaluddin A., Abdul Syukor, S., \& Saidi, N. (2017). Gender and vulnerable types among vulnerable member in malaysia fisheries and aquaculture community. International Journal for Studies on Children, Women, Elderly and Disabled, 2(6), 32-37.

Zainalaludin, Z., Saidi, N., \& Loh, H. C. (2020). Triangulated relationship between gender, vulnerability and poverty among the vulnerable fisheries community member in Peninsular Malaysia. Malaysian Journal of Consumer, 35, 58.

Zainudin, L. M., Zein, A., Idris, M. H., \& Luqman, W. (2019). Socio-economic profile comparison of fishermen community in Kuala Marang and Seberang Takir, Terengganu, Malaysia. Journal of Sustainability Science and Management, 14(6), 130-142.

Zarina, M. N., \& Anton, A. A. (2012). A Preliminary Study of Asset Accumulation among Single Mothers in Malaysia. In 2012 International Conference on Economics, Business and Marketing Management IPEDR, 29, 186-191. 